\title{
Urban shrinkage and housing in a post-socialist city: relationship between the demographic evolution and housing development in Łódź, Poland
}

\author{
Ewa Szafrańska ${ }^{1}$ (D) Lydia Coudroy de Lille $^{2}$ - Jarosław Kazimierczak ${ }^{3}$
}

Received: 1 December 2017 / Accepted: 18 September 2018 / Published online: 25 September 2018 (c) The Author(s) 2018

\begin{abstract}
For several decades, urban shrinkage has been a common pathway of demographic development for many large cities throughout Europe. Although this process began after the collapse of communism in most countries in Central and Eastern Europe (CEE), it should not be interpreted merely as a consequence of systemic transformation. This process was accompanied by the rapid withdrawal of state involvement in the housing sector, which resulted in an escalation of the housing shortage inherited from the socialist period. Thus, the aim of this article is to present a perspective of shrinking in CEE, which is often marginalized in the global discourse on shrinkage. The main purpose is to investigate the relationship between housing and demographic changes after the collapse of communism and answer the following question: Is the old housing structure a positive legacy, a patrimonial inheritance, or a burden in the context of demographic decline? Methodologically, this paper is a case study illustrating the transformations of housing within the context of the historical and spatial demographic development in the selected city. We focus our attention on the example of Łódź, Poland, which reflects the entire CEE spectrum of problems associated with shrinkage while presenting some particularities. However, the shrinkage phenomenon in Łódź also presents an opportunity for improving future housing options. Within a wider context, this example can be considered a lens for the very complex demographic and housing situation of CEE cities. This case shows that legacies of the communist regime influence the relationship between the demographic decline and housing situation and that even a city with a high range in the urban network can be affected by a severe decline.
\end{abstract}

Keywords Central-Eastern Europe $\cdot$ Housing shortage $\cdot$ Łódź $\cdot$ Poland $\cdot$ Post-socialist city - Urban regeneration - Urban shrinkage

Ewa Szafrańska

ewa.szafranska@geo.uni.lodz.pl

Extended author information available on the last page of the article 


\section{Introduction}

Urban shrinkage is a common contemporary phenomenon occurring on a global scale; however, the most affected areas are well-developed countries of North America and Europe (Oswalt and Rieniets 2006). This is the reason why the concept of urban shrinkage has propagated worldwide, triggering researchers' interest in the subject and leading to numerous comparative studies conducted by Beauregard (2009), Haase et al. (2016a, b), Martinez-Fernandez et al. (2016), Turok and Mykhenko (2007, 2008) and Wiechmann and Pallagst (2012), among others. According to the project "Cities Regrowing Smaller" (CIRES), ${ }^{1}$ a shrinking city is defined as a functional urban area with a minimum population of 5000 residents in its core city (or specific district) that has faced a remarkable population loss for at least 5 years (in recent years or in some former period) and/or is undergoing a long-term or episodic economic, social, or cultural transformation that has symptoms of a structural crisis. This definition shows how complex this process is. In recent studies on urban shrinkage, the most significant determinants of this process include economic transformation, suburbanization, demographic transitions, and structural changes, such as political change and environmental contamination (Haase et al. 2013; Reckien and Martinez-Fernandez 2011; Schatz 2010; Wiechmann and Bontje 2015); other determinants of urban shrinkage include armed conflicts and natural catastrophes (Krzysztofik et al. 2015; Oswalt and Rieniets 2006). However, structural economic crisis is considered to be the most crucial factor for urban shrinkage. It is linked with high unemployment rates, the degradation of residential resources, and a particular intensification of social problems (Haase et al. 2014; Stryjakiewicz et al. 2012). According to Cunningham-Sabot and Fol (2009), another key factor of the recent urban shrinkage phenomenon is globalization, especially in the case of well-developed countries in northern areas; furthermore, these scholars claim that the decline of large cities is clearly the result of the redistribution of production at the international scale. Whereas urban shrinkage is a very complex and multidimensional phenomenon, as underlined by many academics such as Audirac et al. (2012) and Haase et al. (2014), in most research, this phenomenon is grounded mainly in the population criterion due to unrestricted access to demographic statistics, which undoubtedly facilitates comparisons between cities. However, in the case of intra-urban-scale analyses based on comparisons between neighbourhoods, it is crucial to implement not only demographic indicators, but also several economic and/or spatial indicators of urban shrinkage, as was done by Špačková et al. (2016) and Temelová et al. (2016), for example.

Turok and Mykhnenko (2007, 2008), who examined urban shrinkage from a historical perspective, found that it has been a common process throughout Europe since the 1960s. However, significant differences have been observed between Western and Central-Eastern Europe (CEE) mainly because of the various political, economic, and social circumstances of urban development during the second half of the twentieth century in Europe (Haase et al. 2013). Regarding the past 3 decades of urban shrinkage, the much higher scale and greater dynamics of depopulation in post-socialist CEE countries can be considered a consequence of the political and economic upheaval of the 1990s. However, urban shrinkage should not be interpreted merely as a consequence of this systemic transformation because a demographic decline has been observed since

\footnotetext{
1 The international research project "Cities Regrowing Smaller-Fostering Knowledge on Regeneration Strategies in Shrinking Cities across Europe" (CIRES) was implemented under the COST Action TU0803 with the participation of scholars representing 26 countries in Europe.
} 
the 1980s in countries such as Hungary and Bulgaria (Mladenov et al. 2008) and in the nineteenth century in certain industrial cities in Germany (Roth 2011). Haase et al. (2016b) attempted to systemize the attributes of depopulation as key indicators of urban shrinkage in cities of former CEE socialist countries. The main attribute was systemic transformation, the catalyst for urban depopulation directly connected with economic crises and the loss of jobs, mainly in industry, leading to impoverishment in societies, reduced fertility rates, and economic migration. These observations are consistent with other research indicating the key factors of urban shrinkage in CEE cities, especially in CEE post-socialist countries such as Poland, the Czech Republic, Slovakia, and Hungary, which were the first to participate in European Union (EU) accession. The principal factors in those countries are a negative fertility rate and outmigration because of (1) economic reasons, with migration primarily to Western European countries occurring after the accession of CEE countries to the EU (Stryjakiewicz 2013) and (2) changes in lifestyle that have particularly promoted urban-to-rural migration, with migration mostly occurring to suburban areas and resulting in the urban sprawl of post-socialist cities (Cirtautas 2013; Geshkov 2015; Stryjakiewicz 2013). In other CEE countries, outmigration is attributed to political factors, such as the attitude of the state towards Russian-speaking minorities, especially in Latvia (Bayou and Le Bouhris 2017).

As a result of the complex economic, spatial, and social circumstances of urban shrinkage, managing it, including the rational management of housing (Kabisch et al. 2012; Radzimski 2016), will likely represent one of the most essential problems in the sustainable development of post-socialist cities in the few next decades (Neill and Schlappa 2016). Examples of East German cities (in the former German Democratic Republic) show that their rapid depopulation after German reunification in 1990 generated a large number of abandoned houses, mainly in large, peripheral modernist housing estates from the socialist period in addition to downtown areas. Unused residential buildings became a crucial problem for housing policies in East German cities, forcing the local authorities to demolish these buildings as part of urban regeneration programmes (Bernt 2009; Haase 2006; Wiechmann 2009). The housing situation in other post-socialist countries in CEE is very different from that of Eastern Germany because of the housing shortage inherited from the socialist period.

Thus, in this context, this paper will focus on the key question of the role of housing in the process of shrinking. Housing is a part of the material structure of the city and of its landscapes. It is made of houses and blocks, the usage time of which is very long, sometimes spanning centuries. The decline in the population creates a situation in which a significant part of the housing stock is empty. Hence, the research problem is posed by the following question: Is the old housing structure a positive legacy, a patrimonial inheritance, or a burden in the context of demographic decline? This issue could be considered from at least two perspectives. On the one hand, the situation created by this decline may be positive because the new balance between the housing stock and the demographic situation offers opportunities to improve the housing situation of the remaining inhabitants, especially if some of the dwellings are overcrowded. The empty housing stock, especially the older buildings, can also be shifted to activities with a higher rental value, such as offices, retail, or hotels. Entire blocks can also be demolished, and the land can be used for other purposes, including new open spaces. On the other hand, housing vacancy is sometimes one of the major causes of demographic decline when it appears that the offer does not match the expectations of the existing or potential residents. Vacancy is a challenge because those empty flats must be maintained without rental income or the economic contributions of their inhabitants. Thus, the degradation of the existing housing stock is most 
likely to increase because its maintenance is a burden for the landlords (private or public), contributing to the economic depression of the given territory.

The collapse of state socialism had a dramatic impact on the economies of Central and Eastern European countries and brought significant changes to the local housing market. Post-socialist countries and their cities introduced new, mainly market-oriented, institutional arrangements regulating the ways of city management and spatial planning (Holm et al. 2015). Responsibility for the development and maintenance of housing was no longer in the hands of the state (Struyk 2000). In the case of Poland and many other post-socialist countries, this meant that the state lost the role of the main spatial planning and main investor in the country's housing structure. The rapid withdrawal of the state from the housing sector, through the drastic reduction of state subsidies and reduction of direct supplies, led to the escalation of the housing crisis that has accumulated over the decades of socialist rule (Kovács 1999; Stanilov 2007; Coudroy de Lille 2013). In the first decade after the change of the political system, the situation has not only improved, but even deteriorated (Tsenkova 2000; Stanilov 2007). The decline in housing construction was accompanied by a relatively young age structure, characteristic of post-socialist cities at the turn of the 1980s and 1990s, and a rapid increase in the percentage of single-person households. This unfavourable situation was deepened by the severe housing shortage inherited from the communist period. Before 1990, this deficit was underestimated by the fact that many people shared their flats with others (in Poland, mainly with adult children and/or older parents). The shortage of flats in Polish cities has been strengthened by the poor condition of a large part of the old, unfinished housing stock. In 2002, it was estimated that at least about 7.5 million dwellings, i.e. $64 \%$ of all resources, require significant repairs (Węcławowicz 2007).

The aim of this paper is to present the perspective of CEE countries that is often marginalized in the global discourse in the area of urban geography (Bański and Ferenc 2013). The need to include studies on post-socialist shrinking cities in the Western European-oriented debate on current and future urbanization and urban theory was also highlighted by Sjöberg (2014) and Haase et al. (2016b). In our research, we focus our attention on the example of Łódź, Poland, one of the largest and fastest-shrinking post-socialist cities in Europe reflecting the entire spectrum of economic, social, cultural, and spatial problems linked to CEE urban shrinkage.

\section{Methodological framework}

As has been already stated, this paper will address the issue of the relationship between social and demographic evolution and housing. This relationship is complex because housing represents part of the legacy of the city: houses and blocks are built for decades, even for centuries, whereas population changes (not only the number of inhabitants, but also the structure of households and the age of the population) increase the variability of the demand for housing over time. Housing can be considered a part of the problem of demographic decline as well as a part of the solution. Such a dichotomy is especially true in the case of Łódź because the housing stock is very old in the central part of the city compared with that in other Polish cities (Polityka Mieszkaniowa 2020+2012). The area of the city most affected by the depopulation process is downtown Łódź (Fig. 1), which is filled with the oldest urban factories in the city that were not destroyed during the Second World War. 


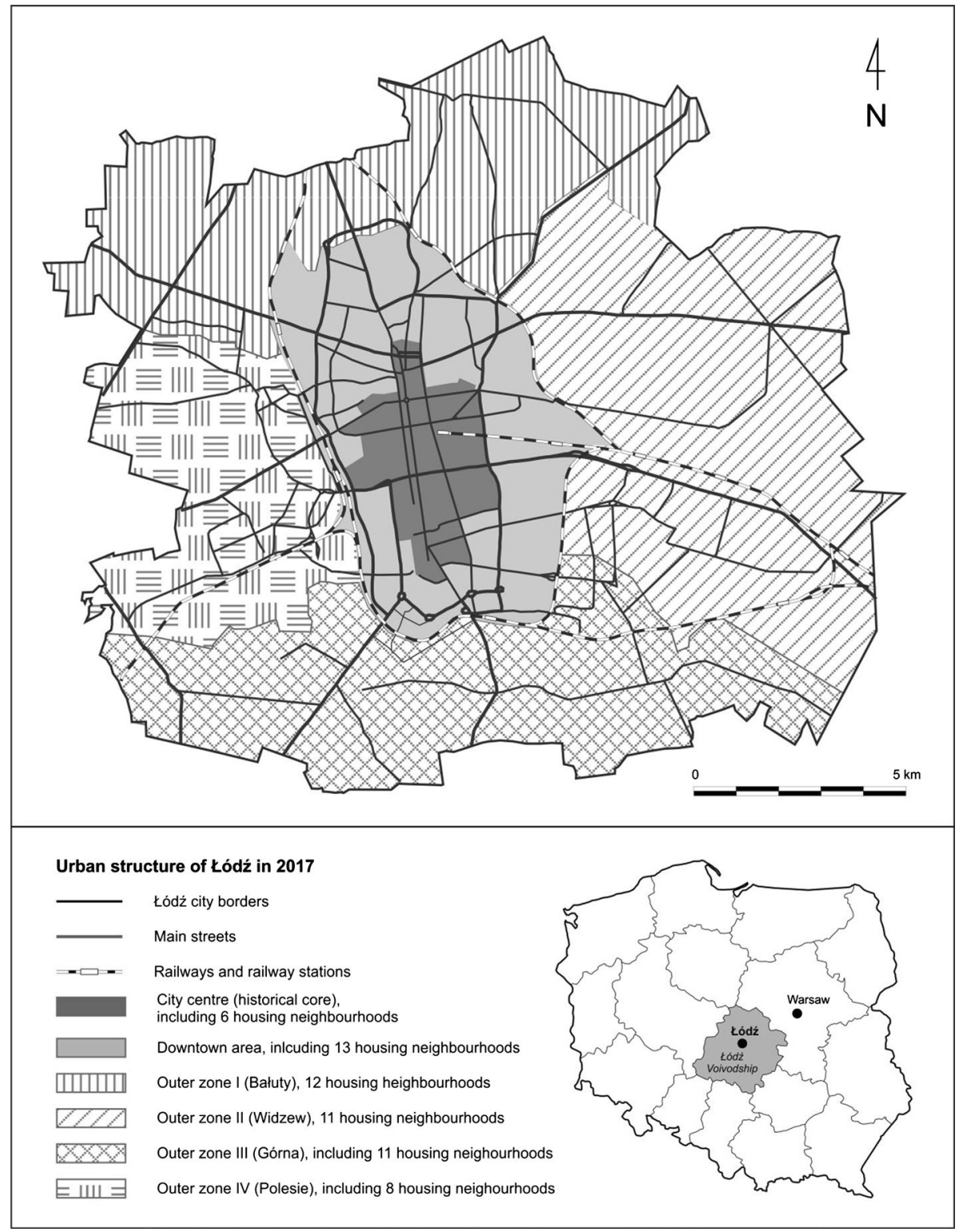

Fig. 1 Urban structure of Łódź in 2017. Source: Authors' compilation

Approximately $65 \%$ of the residential buildings in downtown Łódź were constructed before 1944, and most of them offer very bad living conditions (Figs. 2, 3).

In the context of the urban shrinkage process in CEE post-socialist cities and housing issues, sorely bad technical conditions and living standards make Łódź a unique case. Łódź is a special case among shrinking European cities because the city is the head of the Łódź 
Fig. 2 A vacant and run-down tenement house at 49 Kilińskiego Str. in Łódź historical core. Source: Authors' archive, 2015

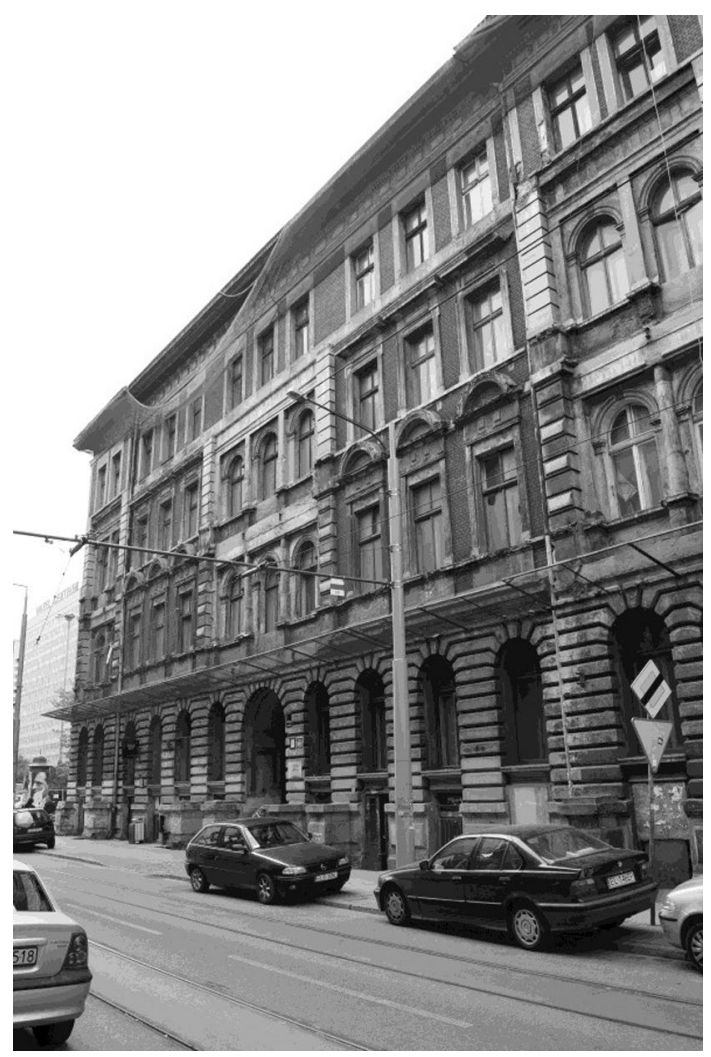

Voivodeship ${ }^{2}$ and therefore fulfils economic, administrative, and cultural functions at a regional level. Indeed, shrinking European cities are generally small or medium in size (Turok and Mykhenko 2007), whereas Łódź belongs to the top of the urban hierarchy in Poland and still aspires to develop as a top metropolis in the country and CEE (Coudroy de Lille and Wolaniuk 2005). This ambition is reflected in the "New Łódź City Centre" (Nowe Centrum Łodzi), one of the largest large-scale urban regeneration megaprojects in Europe (Kazimierczak 2014a, b, c; Kazimierczak and Kosmowski 2017) (Fig. 1). To understand why such a large and important city is now shrinking, we will show that from its very beginning, Łódź has been a singular city in Polish and European urban history. To develop our consideration, achieve the stated objective, and answer the research question, we decided to implement a case study method.

Robinson (2006) argues that to analyse spatial phenomena in cities, we must consider the diverse development paths that determine contemporary development processes. Regarding this statement, each city is exceptional; thus, methodologically, this paper is a case study that illustrates transformations of the housing situation in the context of demographic development in a selected city both temporally and spatially. In our analysis, we

\footnotetext{
${ }^{2}$ A voivodeship is the unit of the highest level administrative subdivision of Poland (at the NUTS2 level) corresponding to a "province" in many other countries. Łódź Voivodeship with an area of 18,219 $\mathrm{km}^{2}$ and a population of over 2.5 million (in 2016) is one of the 16 voivodeships in Poland.
} 
Fig. 3 Neglected tenement house at 12 Narutowicza Str. in Łódź historical core renovated with public funds. Source: Authors' archive, 2015

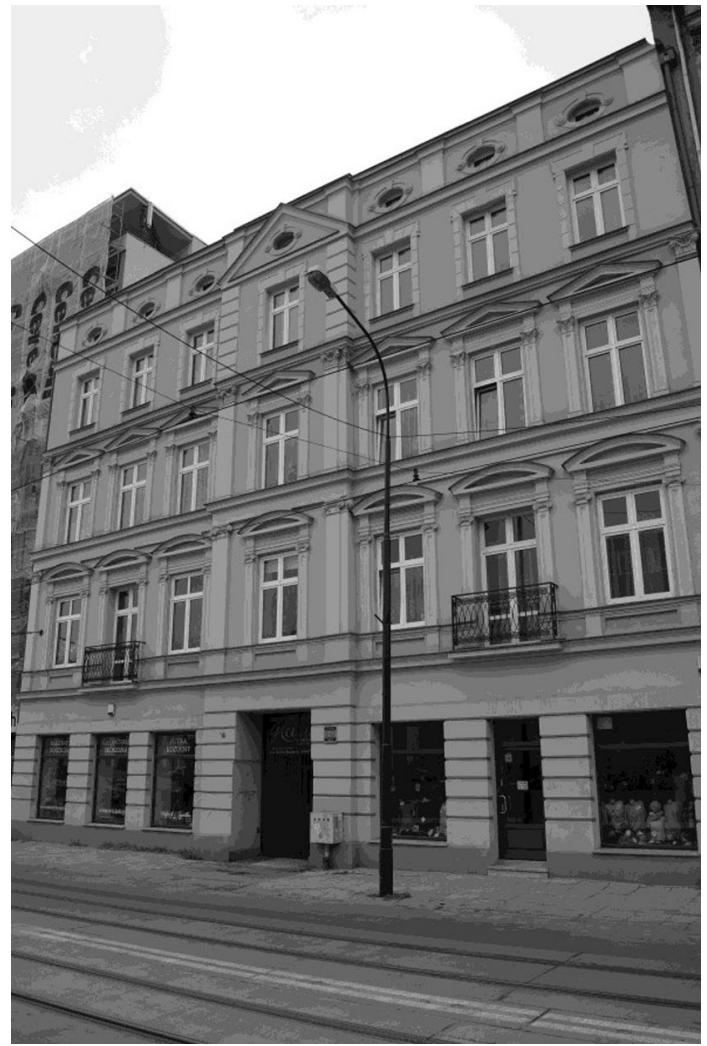

used a single case study method that, thanks to its specificity, enables an identification of the properties of the locally investigated issue. Case studies are frequently used in urban geography for in-depth research despite the criticism of the case study approach. This criticism is concerned with the limitation of the method connected with the argument that any number of case studies cannot enable analysis that produces consistent and replicable results. However, according to Botterill and Platenkamp (2012), the main response to this criticism is a different type of generalization from case study research that is not statistical, but rather theoretical (analytical). This argument is also underlined by other methodologists such as Guba and Lincoln (1989), Kennedy (1976), and Stake (1998). A single case study is methodologically justified in certain situations for virtues such as the universality, decisive significance, uniqueness, novelty, or longevity of the case (Yin 2014). According to Kennedy (1976) and Yin (2014), the in-depth analysis of a single case enables analytical (theoretical) generalization, which is the logic that allows the obtained results to be transferred to situations outside the analysed case based on the appropriateness of theoretical concepts or principles. Our contribution wishes to discuss whether Łódź is a typical dying city as described in other situations of shrinkage or whether it enlarges the perspectives of knowledge about urban change in Europe because of its uniqueness.

According to Tellis (1997), the case study approach based on various types of data allows for a better understanding of the context of a city undergoing a transformation and makes it possible to provide a better explanation of the processes analysed. A triangulation 
of methods is essential in this approach; thus, the case study of Łódź included quantitative and qualitative methods. Quantitative analyses were performed by investigators (authors) in 2016 and 2017 based on desk research of statistical data obtained from the National Censuses in 1988, 2002, and 2011 (the last three National Censuses in Poland) and other statistical data from the Central Statistical Office (CSO) and the Statistical Office in Łódź. All of these data concern the demographic, socio-economic, and housing situations in Łódź between 1988 and 2011 in the case of the National Censuses and between 1988 and 2016 in the case of other statistical data from the CSO. The qualitative analysis comprised direct observations of urban change in the downtown and large housing estates in Łódź made by investigators (authors) during the fieldwork between 2014 and 2016. Fieldwork was undertaken to identify and fill the potential gaps in the data from the National Censuses, CSO, and Statistical Office in Łódź. The data collection and fieldwork enabled identification of the convergent and divergent changes in the population as well as dwellings and residential buildings over the period of 1988-2013. The results of the investigation were aggregated to 61 Łódź neighbourhoods (see Fig. 6a), which are the smallest morphological units of data aggregation in National Censuses in Poland.

\section{3 Łódź: from rapid growth to spectacular decline and urban shrinkage}

\subsection{City born with a textile industry and "great" immigration}

Łódź is a city located in central Poland just $140 \mathrm{~km}$ from the capital city of Warsaw (Fig. 1). Through the beginning of the nineteenth century, it was a small agricultural town with a population below 1000 inhabitants, but in 1820, the city became one of the new industrial centres devoted to the textile industry. Then, a demographic and economic boom began for Łódź, and the city became the second most inhabited city in Poland with 235,000 inhabitants in 1880 (Kubiczek 1994). Favourable economic conditions in the textile industry due to the unlimited market in the east and a massive inflow of people changed the small town into one of the largest industrial cities in this part of Europe, with a quarter of the industrial production of the Kingdom of Poland at the end of the nineteenth century originating from Łódź. The pace of the demographic and spatial development in Łódź in the nineteenth century was comparable only to the fast development of great industrial North American cities in the nineteenth century as well as some Western European industrial cities in the same period, e.g. Manchester in the UK, Saint-Etienne and Roubaix in France, and German cities in the Ruhr region. By 1925, the population of Łódź grew to 500,000 inhabitants (Jakóbczyk-Gryszkiewicz 1997). During the Second World War, Łódź lost almost one-third of its population from 672,000 to 496,900 inhabitants. However, the city itself did not receive much damage during the War in contrast to other Polish cities, and that had far-reaching consequences for the current living conditions in Łódź.

During the socialist period between 1945 and 1989, Łódź was still the largest centre of the Polish textile industry, and it remained so until the end of the socialism era. The city had a fast-growing population during that era. The ratio of people employed in the industry decreased systematically but slowly after the Second World War. In the 1970s, nearly $60 \%$ of employees worked in the industrial sector (228,000 workers). In 1980, this proportion had decreased to $50 \%$ (204,000 workers), and by 1990 , it fell to $38 \%(93,000)$ 


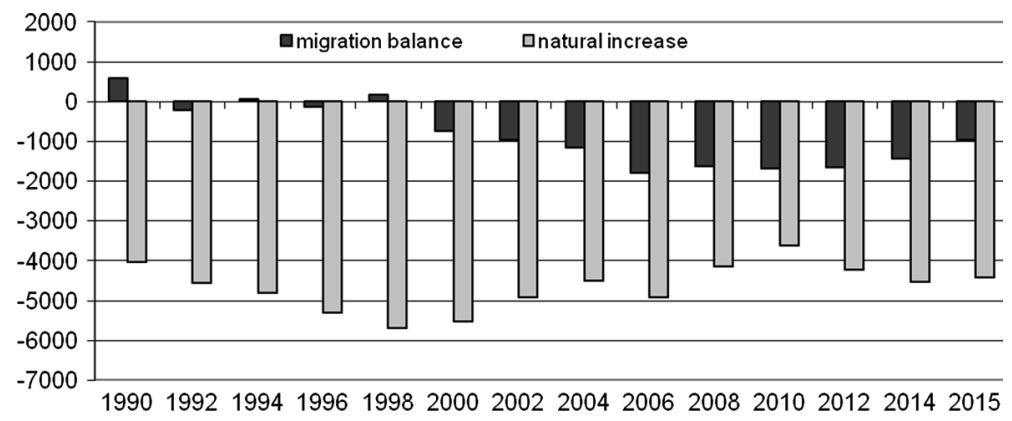

Fig. 4 Natural increase and migration balance in Łódź from 1990 to 2015. Source: Authors' compilation based on data of the Statistical Office in Łódź

(Jakóbczyk-Gryszkiewicz 1997). Most of them were still employed in the textile and garment industry. ${ }^{3}$ Simultaneously, the population of the city grew steadily until the end of the 1980s. This increase was driven by high birth rates and labour migration (JakóbczykGryszkiewicz 1997). The highest population of 853,480 inhabitants was reached in 1988 just before the fall of the communist regime.

\subsection{Demographic decline of Łódź after the collapse of communism}

As a result of political changes at the turn of the 1980s and 1990s, the textile industry in Łódź collapsed, and the economic structure of the city changed significantly. Łódź became a city of high structural unemployment and a declining population. Over the past 3 decades from 1988 to 2017, the city lost 163,060 inhabitants (i.e. $19 \%$ of its population), and it is the fastest-depopulating large Polish city. In 2007, Łódź lost its position of the second-largest Polish city; according to the CSO in Poland, Łódź is currently the third-largest city in Poland with 690,420 inhabitants (in December 2017). Due to this significant depopulation, Łódź is currently recognized in the literature as a "shrinking" city (Mykhnenko and Turok 2008; Stryjakiewicz and Jaroszewska 2014). Furthermore, the CSO estimated that only 542,732 people will live in Łódź in 2040. Thus, the city will shrink in population by $36.4 \%$ between 1988 and 2040. The most negative demographic predictions for Łódź elaborated by the CSO show that there will be only 484,800 inhabitants in Łódź in 2050. As a result, this city can be considered one of the largest and fastest-shrinking cities not only in Poland, but also in CEE during the first half of the twenty-first century.

The population decrease in Łódź in 1988-2015 was an effect of natural population decline (the surplus of deaths over births) and negative net migration (Fig. 4). The general fertility rate (number of live births per 1000 women aged 15-49) in Łódź decreased from 39.8 to 36.6 during 1988-2015. Much of this decline has been caused by the delay in motherhood and the reduced number of children per family (Szukalski 2012). This reproductive behaviour, considered within the concept of the second demographic transition (Lesthaeghe and van de Kaa 1986; van de Kaa 2003), is typical throughout Poland

\footnotetext{
3 In 1980, 48,9\% of the industrial value was produced by the textile industry (Liszewski 2009). In 2007, textile production, apparel, and furriery businesses together hired $40 \%$ of the labour forces in manufacturing ( Eódź in figures, 2008, City of Łódź and CSO, p. 21).
} 


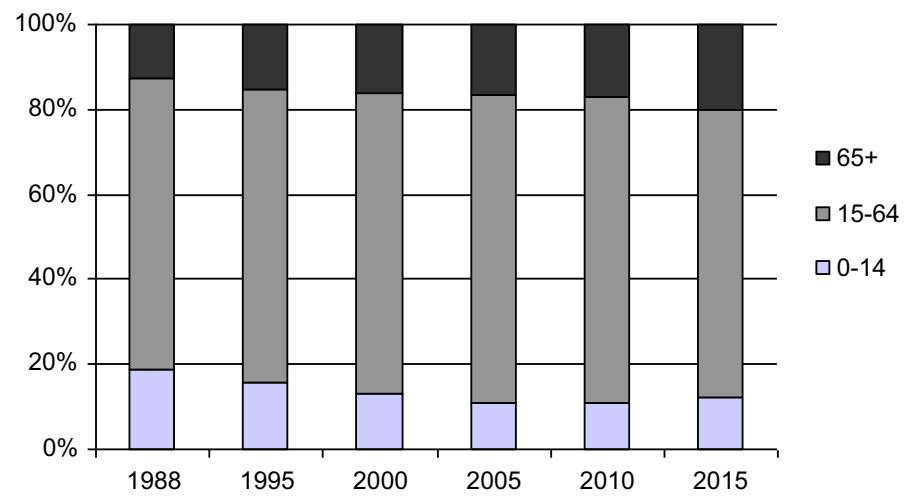

Fig. 5 Changes in the age structure in Łódź population in 1988-2015. Source: Authors' compilation based on data from the Central Statistical Office in Poland

and other post-socialist countries (Kabisch et al. 2008). The difficult economic situation in Łódź after 1989 contributed to a deepening of this process because of the relationship between economic uncertainty and reproductive behaviour. This relationship, although indirect, was found in post-socialist countries during the first decade of transformation (Brainerd 2012). The impact of migration on the population decrease was lower than that of the natural decline; however, it contributed to this trend. In recent decades, a surplus of outflow over inflow was observed every year; however, in recent years, a reduction in the negative migration balance has been observed (Fig. 4). Considering the structure of outflows and inflows, the data indicate that a significant increase in the outflow has occurred to rural areas, which are mostly located in the Łódź Voivodeship. The significant increase in the proportion of outflows to the Łódź region is a sign of the development of the suburbanization process. More detailed data show that the majority of outmigration is concentrated in the areas surrounding the city. However, this phenomenon is still not advanced compared with that of other large cities in Poland. The data also show a low number of registered migrations to and from abroad, but not all of these flows are registered in Poland because much emigration from Poland is indeed part of the circular mobility inside Europe and is not systematically registered. ${ }^{4}$

Furthermore, over the past few decades, the population of Łódź was affected by a significant process of ageing. Between 1988 and 2015, the proportion of children decreased from 18.9 to $12.3 \%$, while the percentage of seniors (over 65 years old) grew from 12.6 to $20.3 \%$ (Fig. 5). In the same period, the index of ageing (the ratio of seniors to children) increased from 66.7 in 1988 to 171.8 in 2015 . This process was caused by various factors: first, by the decline in birth rates and increase in life expectancy; second, by the delay in motherhood; third, by the outmigration of working-age people because of relatively high unemployment; and fourth, by the process of suburbanization, which mainly involved younger and middle-age people moving to the suburbs (Kabisch et al. 2008).

According to the population projection of the CSO, the current process of ageing is predicted to continue in the future. The forecast shows that the proportion of seniors will

\footnotetext{
${ }^{4}$ See, for example, Recent Trend in International Migration in Poland, report of the Centre of Migration Research, 2015, available on http://www.migracje.uw.edu.pl/wp-content/uploads/2016/04/WP86144_1.pdf.
} 
increase dramatically (from $20.3 \%$ in 2015 to over $27 \%$ in 2040), whereas the share of the pre-working and working-age population will decrease. Therefore, Łódź is characterized by not only the most significant predicted loss of inhabitants, but also the most negative structural change in the population compared with other large Polish cities.

\section{Population distribution change and housing situation in post-socialist shrinking Łódź}

\subsection{Living conditions and population distribution changes}

The current situation of housing in Łódź is also very particular in Poland. Compared with the significant loss of population between 1988 and 2015, the number of households increased because of the growing number of small (especially one-person) households. According to the last National Census in 2011, the share of one-person households increased from 25 to $34 \%$, whereas the share of larger households with 3 or more persons declined from 44 to $35 \%$ during 1988-2011.

The population of the city is highly concentrated in two different morphological types of buildings. The first type is tenement houses in the historical downtown of the city located inside a railway ring line (see Fig. 1). In the city of Łódź, $26 \%$ of residential buildings were constructed before 1944, while in the downtown area, this proportion increases to $65 \%$. Most of them offer very bad living conditions. The National Census in 2002 indicated that $50 \%$ of the tenement houses in downtown Łódź lacked central heating, 12\% lacked toilets, and $30 \%$ lacked a connection to the sewage system. The predominance of municipal ownership of dwellings, bad living conditions, and low-quality public spaces were the key factors that forced local authorities to designate an essential part of the historical core of Łódź as a crisis area to be revitalized in the following decade (Kazimierczak 2014c). As a result, 20 areas in the downtown area were designated for urban regeneration during 2014-2020 to be co-financed by the EU (Fig. 6a). These areas cover 379.28 ha in total, accounting for only a portion of the 1783 ha of the run-down area in downtown Łódź that requires immediate revitalization. ${ }^{5}$ Furthermore, the City Council analysis shows that $75 \%$ of the buildings located in the run-down area of downtown Łódź are in bad or very bad technical conditions, with $55 \%$ in need of modernization and $25 \%$ in ruins and requiring demolition (Kaczmarek et al. 2018; Polityka mieszkaniowa Łodzi 2020+).

Renovating tenement houses and increasing the share of private ownership dwellings are crucial foundations of the current Łódź housing policy. These goals are implemented by the City Council through revitalization and other modernization programmes, such as "Mia100 Kamienic" ("City of Tenement Houses"), the aim of which was the renovation of over 100 municipal tenement houses in downtown Łódź since 2011. Downtown Łódź represents the area in the city most affected by the political and economic transitions of the 1990s and consequent negative population changes. Although the share of the population in the outer zones of Łódź increased between 1988 and 2013 from 37.05 to $45.48 \%$, the downtown (historical core, Fig. 6a) shrunk from 23.03 to $19.85 \%$, and

\footnotetext{
${ }^{5}$ Run-down areas in downtown Łódź cover $6.08 \%$ of the whole city area and $10.63 \%$ of the built area in the city. Additionally, it is inhabited by 152,292 people, which is $22.83 \%$ of the population of Łódź (Gminny Program Rewitalizacji Łodzi 2026+).
} 


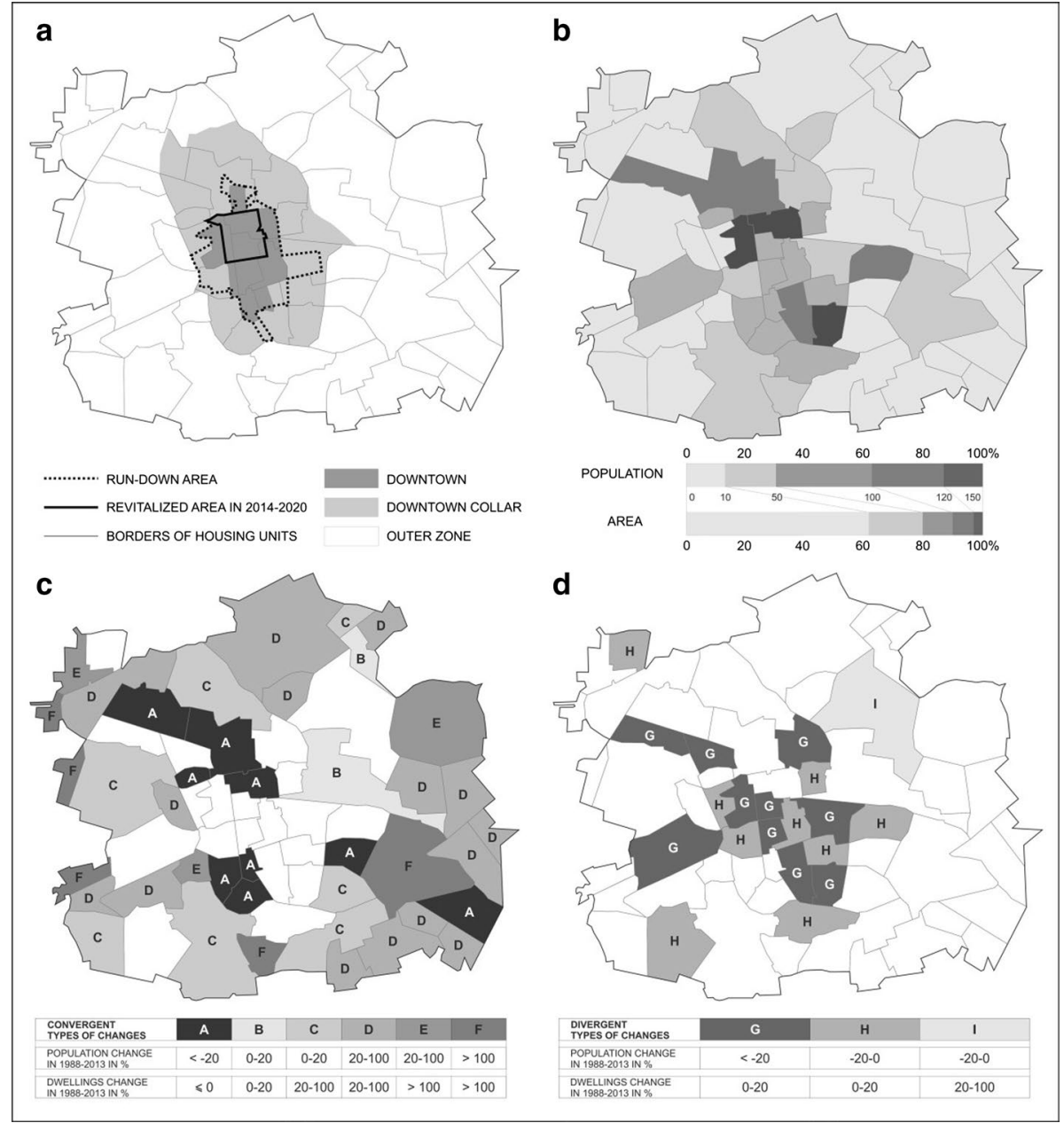

Fig. 6 Spatial and demographic conditions of Łódź during 1988-2013: a run-down and revitalization areas in Łódź in 2013; b spatial concentration of the population in Łódź in 2013; c convergent population and dwelling changes in Łódź during 1988-2013; and d divergent population and dwelling changes in Łódź during 1988-2013. Source: Authors' compilation based on data from the CSO data and the Łódź City Council

the so-called downtown collar (area of current development of the downtown area inside the railway ring line, Fig. 6a) shrunk from 39.92 to $34.67 \%$ during the same period.

The second type of highly concentrated residential area constitutes large housing estates that were constructed in the socialist period and located along two main communication axes (i.e. east-west and north-south) of the city (see Figs. 1 and 6b). Residential buildings in these areas offer much better living conditions, especially compared with the tenement houses in the run-down downtown area (the inner city, which is the historical core of the downtown area and the downtown collar). This assessment is reflected in research showing the satisfaction of Łódź inhabitants with their place of residence according to city districts (Szafrańska 2016; Szafrańska and Mularska-Kucharek 
2016). In the central district of Łódź (Śródmieście), which can be identified as the historical core of the downtown area, the inhabitants' satisfaction regarding their place of residence is much lower than that in other districts in the city. The same research shows that inner city tenement houses are the least preferred types of residential buildings and much less preferred than blocks of flats from the socialist period (Szafrańska 2016). This situation is typical for most post-socialist CEE cities (Węcławowicz 2007), especially for post-industrial cities with a neglected nineteenth-century urban fabric in downtown areas as a result of the ideologically motivated "modernization gap" in the state-socialist period (Węcławowicz 2007; Wojnarowska 2011).

The most significant population loss occurred in areas with a high percentage of lowquality, standard, old housing resources and areas of blocks of flats built in the 1950s and 1960s. Furthermore, the population living in the central area of the city is much older than that living in the outskirts. The demographically oldest areas are located in the downtown collar (see Fig. 6a). In certain housing districts in this zone, the percentage of the population at retirement age in 2010 was higher than one-third. Although a retirement pension in Poland is common, it is low and is sufficient only to cover modest maintenance costs. ${ }^{6}$ In this situation, the concentration of this population group (elderly and disabled due to age) in old housing resources not adapted to their needs (densely built-up areas that are mostly without elevators and often do not have bathrooms, and some are without toilets) may lead to the social marginalization of these areas. Another key point to remember is that the central area of the city is characterized by a relatively high rate of unemployment, a larger number of recipients of social assistance, and a relatively low educational level. The concentration of these phenomena can also lead to segregation and social exclusion in this area, where the formation of enclaves of unemployment, poverty, and social pathologies is observed (Szafrańska 2008; Warzywoda-Kruszyńska et al. 2003). Therefore, in addition to the depopulation of Łódź, a crucial problem is the structural change in its population, which raises questions regarding the ability of Łódź and other post-socialist and post-industrial shrinking cities to adapt to such an evolution of the features of current and future housing stocks.

\subsection{Housing situation in post-socialist Łódź in the context of depopulation}

The investigation shows two different patterns of population and dwelling changes in Łódź during 1988-2013. The first one constitutes convergent changes with a visible expressive dependence between the decrease in population and dwellings and the increase in population and dwellings (Fig. 6c). These patterns are mostly observed in new residential areas in the outer zones of Łódź, and they are a result of the outward migration to newly built, detached single-family houses in the inner suburbs. These new residential areas are populated by affluent individuals as reflected by the spatial distribution of mansions. According to Dzieciuchowicz and Groeger (2016), no new mansions were constructed in the inner city of Łódź during 1990-2014, whereas in the outer zones, 22 mansions were built in 2008-2009 alone. However, the lack of mansion construction does not correspond to a lack of new housing investments in the central part of the city because new multi-family

\footnotetext{
${ }^{6}$ According to the country's social security institution (ZUS), the average monthly elderly pension in Poland was PLN 2,100 in 2016 (ca. 500 EUR), while the average gross wage in the national economy was 4,019 PLN in 2016 (ca. 1,000 EUR).
} 


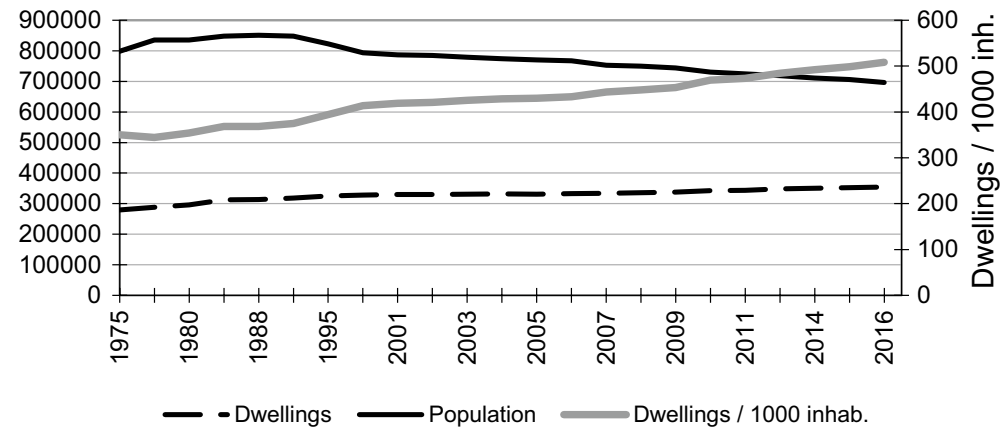

Fig. 7 Population and housing stock development in Łódź during 1975-2016. Source: Authors' compilation based on data from the Central Statistical Office in Poland

Table 1 Changes in the relationship between the number of households and the number of dwellings in Łódź from 1978 to 2011. Source: Authors' compilation based on data of National Censuses 1978, 1988, 1995, 2002, and 2011

\begin{tabular}{llll}
\hline National census year & Dwellings (D) & Households (H) & $\begin{array}{l}\text { Statistical deficit or } \\
\text { surplus of dwellings } \\
\text { (H/D) }\end{array}$ \\
\hline 1978 & 288,067 & 323,684 & 1.12 \\
1988 & 313,764 & 342,191 & 1.09 \\
1995 & 324,800 & 346,900 & 1.07 \\
2002 & 331,668 & 352,000 & 1.06 \\
2011 & 343,200 & 324,900 & 0.95 \\
\hline
\end{tabular}

buildings have been constructed in downtown Łódź, especially on numerous urban infill and undeveloped plots. According to Holm et al. (2015), these developments have strengthened the gentrification process and increased the socio-economic polarization in central Łódź. Since the beginning of the twenty-first century, post-industrial areas have become attractive for developers, who have refashioned old historical factories into luxurious apartments and lofts or constructed new residential buildings on post-industrial urban infill after demolition (Kaczmarek et al. 2018).

The second pattern of population and dwelling change during 1988-2013 is divergent change, which is characteristic of downtown Łódź and large housing estates from the 1970s and 1980s (Fig. 6d) because of the decline in population and increase in new dwellings. However, the growth of new dwellings in these areas has not been as high as that in outer zones despite the construction of only multi-family buildings.

Although the population decreased constantly in Łódź between 1988 and 2015, the number of dwellings grew slowly over the same time period (Fig. 7). The last National Census in 2011 showed a surplus in the number of houses over the number of households; thus, the housing shortage appears at first glance to have been resolved by depopulation and the decline in the number of households since 2002 (Table 1).

However, resolving the housing shortage does not mean that the general living conditions have improved, because the housing situation must be considered in the context of 
Table 2 Selected demographic and housing indicators in Łódź (in 1988-2013) in comparison with other large Polish cities (in 2013). Source: Authors' compilation based on National Censuses (1988 and 2002) and data from the Central Statistical Office (2013)

\begin{tabular}{|c|c|c|c|c|c|c|c|}
\hline \multirow[t]{2}{*}{ Indicator } & \multicolumn{3}{|l|}{ Łódź } & \multirow{2}{*}{$\begin{array}{l}\text { Cracow } \\
2013\end{array}$} & \multirow[t]{2}{*}{ Poznań } & \multirow[t]{2}{*}{ Warsaw } & \multirow[t]{2}{*}{ Wrocław } \\
\hline & 1988 & 2002 & 2013 & & & & \\
\hline Number of inhabitants (in thousands) & 854.3 & 789.3 & 711.3 & 758.9 & 548.0 & 1724.4 & 632.1 \\
\hline $\begin{array}{l}\text { Number of inhabited dwellings (in thou- } \\
\text { sands) }\end{array}$ & 313.8 & 331.7 & 348.2 & 346.5 & 244.3 & 885.7 & 290.3 \\
\hline Average usable floor space in $\mathrm{m} 2$ & 45.7 & 52.1 & 53.7 & 57.7 & 64.9 & 58.8 & 70.8 \\
\hline $\begin{array}{l}\text { Average usable floor space of dwelling per } \\
\text { person in } \mathrm{m} 2\end{array}$ & 17.1 & 21.1 & 26.3 & 26.3 & 28.9 & 30.2 & 32.5 \\
\hline Average number of rooms per dwelling & 2.9 & 3.0 & 3.1 & 3.2 & 3.5 & 3.2 & 3.9 \\
\hline Average number of people per dwelling & 2.7 & 2.5 & 2.0 & 2.2 & 2.2 & 1.9 & 2.2 \\
\hline \multicolumn{8}{|l|}{ Share of dwellings with: } \\
\hline Water supply & 90.9 & 97.0 & 97.3 & 98.8 & 99.7 & 99.4 & 99.3 \\
\hline Separate bathroom & 75.6 & 85.3 & 89.0 & 96.3 & 95.5 & 96.7 & 93.4 \\
\hline Central heating & 70.7 & 78.6 & 80.2 & 87.1 & 85.2 & 94.2 & 84.2 \\
\hline
\end{tabular}

housing conditions and the economic availability of housing, which are still worse than those of other large cities in Poland (Table 2). The deep housing shortage characteristic of the state-socialist era caused by a deficit in housing stock was replaced by a shortage caused by affordability problems. Due to the reduction in the rental sector (less than $4 \%$ of new dwellings built in Poland in $2016^{7}$ ), the lack of a state housing policy, the adoption of neoliberal assumptions that housing is a commodity, and the unfavourable relationship between housing prices and incomes, the housing needs of many households in Poland remain unmet (Salamon and Muziol-Weclawowicz 2015).

A closer analysis of the housing stock shows another dimension of the difficult situation in this field. The housing stock comprises three main types of dwellings that are quite separate in the urban space. Overall, the majority of the housing stock (42\%) still belongs to housing cooperatives ( $26 \%$ for all cities), which built the majority of Polish urban dwellings from the 1960 s to the 1990 s. The next $27 \%$ of dwellings are privately owned by individuals and are predominantly present in the second periphery (houses in inner suburbs). In addition, $22 \%$ are owned by the municipality, and $2.3 \%$ are owned by enterprises, and these buildings are mainly in the downtown. Dwellings are rather small on average $\left(53 \mathrm{~m}^{2}\right)$, especially the public flats owned by the municipality or enterprises $\left(43 \mathrm{~m}^{2}\right)$.

The size of dwellings is related to the ownership structure and reflects the same centre-periphery model. The downtown area of Łódź is still mainly old buildings from the nineteenth century. These rental flats are generally in poor condition because these buildings were nationalized in 1945, and they have since been managed by the municipality. The low level of rentals and the lack of maintenance from the municipality over several decades are responsible for this situation (which is why this phenomenon is called the "modernization gap"). Since the 1990s, the city has recovered its autonomy and attempted to privatize a part of this housing stock, which is why the share of municipal dwellings fell from

${ }^{7}$ CSO, 2017. 
$43 \%$ in 1988 to $22 \%$ in 2011 . Nevertheless, compared with other large cities in Poland, the municipal ownership rate is still high, ${ }^{8}$ which makes revitalization sorely expensive in Łódź. New owners cannot always afford the modernization of buildings; thus, privatization does not necessarily mean better maintenance. In this case, the Act on Regeneration (Journal of Laws [Dz. U.] of 2015, item 1777, and of 2016, items 1020, 1250) adopted by the Polish Parliament in 2015 is essential because it provides for the foundation of Special Regeneration Zones in the most run-down areas in cities and areas where the commune (i.e. the city) may be able to support the modernization of private buildings via public sources.

Compared with the downtown area, the outer zones in Łódź offer better living conditions. These zones can be divided into two different housing areas. The first area includes large housing estates that were built during the socialist period and are located around the inner city (first periphery). The relatively worse living conditions based on the size of the dwelling and the architectural quality are in those that were built in the 1960s. Large housing estates are marginalized in urban regeneration programmes in Poland because most of them are in good condition (Szafrańska 2013, 2014). This is confirmed by the estimation of the level of degradation of Polish cities, including Łódź. According to Ziobrowski and Domański (2010), run-down areas covered at least 120,000 ha, which constitutes $22 \%$ of the built areas in Polish cities, in 2008. Among these areas, the historical downtown areas, post-industrial urban areas, and large housing estates constituted approximately $52 \%$, $20 \%$, and $12 \%$, respectively. Thus, residential buildings in these estates are modernized by cooperatives, which are mostly their owners. Łódź is not an exception. The second housing area in the outer zones of intra-urban suburbs (the second periphery) in Łódź presents a mixed type of detached houses or small housing estates developed after 1990 and traditional houses in a half-rural landscape.

Thus, taking into account the zones of multi-family buildings in which almost twothirds of city inhabitants live, the most essential features of the housing situation in Łódź can be characterized as follows:

(1) Downtown Łódź is the only area where the housing challenge is truly quantitative (decrease of up to $15 \%$ of residential buildings in some downtown neighbourhoods, mainly among buildings constructed before 1944) as well as qualitative. The housing stock is old and in bad condition, and it often does not meet modern standards for living conditions (especially in accordance with nineteenth-century tenement houses); the complicated structure of the ownership of real estate (the area is mixed mainly with fully municipal, partly municipal, and private ownership) as well as the social characteristics make it difficult to engage in revitalization. Furthermore, recent research shows that the perception of downtown Łódź is very negative, which makes it unattractive (Groeger 2002; Wójcik and Tobiasz-Lis 2014).

(2) The large housing estate zone has become increasingly attractive (reflected by a general increase in residential buildings), but the flats are small. Even if the living conditions are technically better, especially compared with the downtown area, the buildings in these housing estates are now more than 30-40 years old, and affluent inhabitants who can afford better housing prefer individual houses or a dwelling in a new housing estate in the suburbs.

${ }^{8}$ The share of municipal ownership is below 15\% on average in Polish cities (2011). 


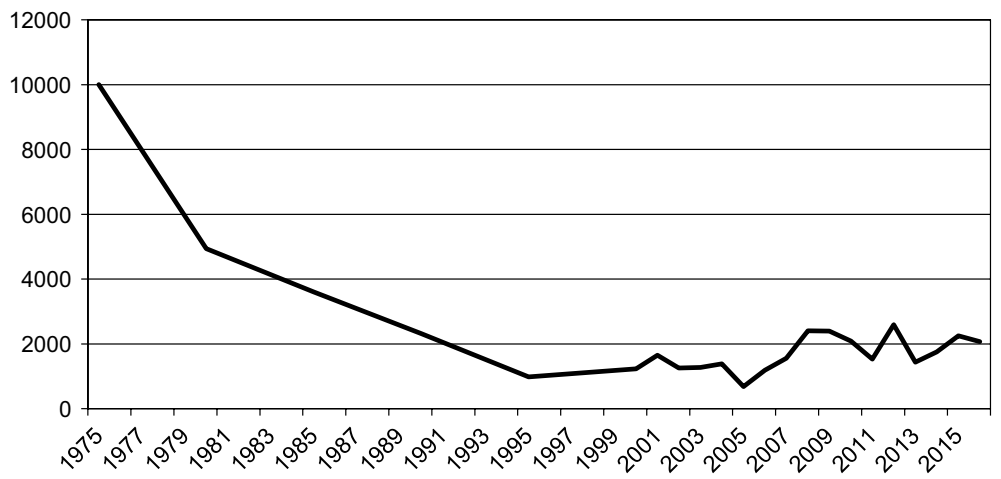

Fig. 8 Housing construction in Łódź from 1975 to 2016. Source: Authors' compilation based on data from the Central Statistical Office in Poland

\subsection{Housing market in Łódź}

What does the housing market look like in Łódź? Similar to other Polish cities, housing construction has been dropping since the 1980s within the national context of a political and economic crisis (Fig. 8). This regression continued into the 1990s, and Łódź has been in a slightly better situation for only a few years. In 2015, the level of housing construction was still lower than that in 1990, which represented a time of radical political and economic change. Furthermore, the situation of Łódź is much worse compared with that of the average Polish city. Only 3 new dwellings per 1000 inhabitants were built in 2016 in Łódź (compared with 4.6 on average in Polish cities). Of course, the contrast with dynamic cities such as Kraków is stunning. Łódź also suffers in comparison with Poznań and even Katowice, both of which have been losing their population since 1990, but maintain a higher housing construction rate (Fig. 9).

Private developers (which are sometimes cooperatives transformed into private corporations) build houses or flats in blocks, which are then sold or rented. These developers built $62 \%$ of the new flats in 2015 , which is a similar proportion to that of other cities in the country. The next share of new housing stock is privately owned by individuals (34\%). The city and cooperatives have built very few dwellings, and enterprises have built none. The number of dwellings in the inner suburbs of Łódź is growing because of the activity of private developers; similar to other cities, they are mainly building flats and houses. The primary decrease in housing units since 1988 has occurred in the downtown collar (see Fig. 6c); however, this situation is not due to a global action of demolition, ${ }^{9}$ but rather due to modernization operations. These flats are usually involved in a functional revitalization (converted into offices) and a morphological transformation (with the joining of one or more flats to make one larger flat).

Almost all of downtown Łódź has been sequentially involved in a strategy of urban regeneration since 2004 because of the high concentration of problems in this area, such as

\footnotetext{
9 According to the 2002 census of the population and dwellings, fewer than 2000 dwellings were intended for demolition, and according to a City Council investigation in 2016, 500 used and unused tenement houses are located in the historical core of the downtown area. These houses will be demolished by 2020 as part of the urban regeneration programs in Łódź.
} 


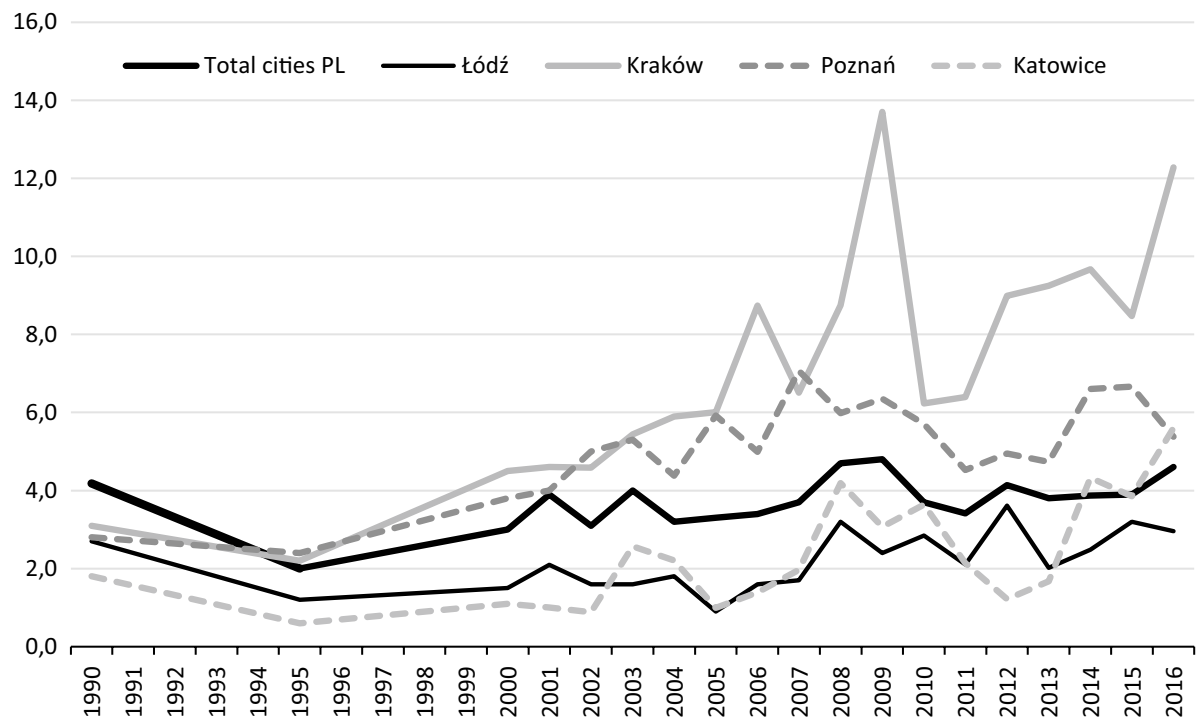

Fig. 9 New dwellings per 1000 inhabitants in some Polish cities compared with all Polish cities during 1990-2016. Source: Authors' compilation based on CSO data

demographic decline, poverty, and environmental and architectural degradation. The main goal of urban regeneration is to create better housing that presents higher technical standards of comfort, fills in open spaces around city blocks, and highlights aesthetic values. This project also aims to raise the social conditions of the population via the provision of social programmes to the local population in parallel with housing revitalization. Almost half of the housing stock in this area still belongs to the city, which represents an opportunity but also a large challenge because the city cannot afford the revitalization alone. Of course, EU funds have provided considerable help; however, the city still has to pay a quarter of the amount. Twelve per cent of the dwellings in the area of urban regeneration are under joint ownership because of the privatization of the municipal housing stock. Such co-owners are usually poor and can hardly bear the heavy modernization costs of houses. Thus, revitalization is making slow progress, and its effects are scattered across the urban landscape.

\section{Conclusions and discussion}

In conclusion, we would like to address two issues: the relationship between the demographic decline and housing situation and the exemplary and unique nature of the case of Łódź.

The analysis of the demographic processes observed in Łódź over the past 3 decades has shown that it is a city characterized by a low migration balance, a negative birth rate, an ageing population, an unfavourable forecast for the population, and a population that has decreased by $18 \%$ since 1988, especially in the historical core of the downtown area. Meanwhile, the housing stock has been growing (+22\% during 1988-2016) because, as 
shown in Fig. 8, the construction of dwellings, though low, has never ceased. However, unexpectedly, fewer than $2 \%$ of the dwellings stand empty. ${ }^{10}$ This situation shows that even when the demographic decline is severe-which is undoubtedly the case here-it does not provoke a fall in the housing stock. In other words, the impacts on the material structure of the city, suggested literally by the term "shrinking", does not happen in its most severe form-the diminution of the housing stock even when the demographic decline itself is severe. This paradox calls for a comparison with other national contexts. In France or in Germany, the most severe cases of shrinkage are often associated with high vacancy rates in the housing stock reaching up to $13 \%$ in the city of Roubaix in the 1990s (Béal et al. 2017). This is generally not the case in Poland or in Łódź in particular, because the country suffers from a structural housing shortage inherited from the communist period that was not resolved by the introduction of the market economy. As a result, another major difference from other industrial cities in Western Europe is that the demolition of low-quality dwellings is very rare and limited to the most fragile tenement houses downtown. In comparison, in France and Germany, thousands of flats have been demolished, albeit in large housing estates, as a response to their lower attractiveness and high vacancy rates. Thus, the chronic housing shortage in Poland-as in many former socialist countries-is responsible for a different relationship between the demographic decline and housing situation. In addition, one of the particularities of this city is the high share of old houses in the inner city, which is a legacy of the lack of investment and modernization during the twentieth century. This legacy generates high costs of maintenance and adaptation and can be considered a burden, especially because this area concentrates a socially disfavoured population.

An essential topic for further discussion is the advantages of shrinkage as initiated by Hager and Schenkel (2003), Kil (2004), Hondrich (2007), etc., in the context of changes in the housing situation. For the case of Łódź, demographic changes in the city as part of the shrinkage process may be assessed positively because the quantitative availability of dwellings has increased. Obviously, economic barriers remain, but these barriers are common for most developed countries and observed in neoliberal policy and post-socialist cities. The improvement of the current housing stock will likely represent a more challenging task because downtown Łódź offers low standards of living. Revitalization and other modernization programmes, including municipal as well as public-private housing co-financed by the EU, may represent key solutions for this situation in most of the shrinking post-socialist cities in CEE. This is why the attention in post-socialist cities has generally not focused on the large housing estates constructed in the 1960s, 1970s, and 1980s. The morphological structure of such cities is mainly a legacy of a booming industrial city from the nineteenth century. For example, the legacy of Łódź is derived from a hyper-capitalist period of urban growth that has obtained patrimonial value, and its technical and architectural aspects are improving (albeit in a scattered way) because of the scale of the task. Indeed, although housing is not directly the reason for the demographic decline, it could be a part of the solution and appears to represent a necessary but insufficient parameter for improving the overall image of the downtown area and inner city to maintain or attract new inhabitants as well as economic activities and investors.

In some aspects, Łódź is definitely similar to other shrinking cities, but it is also very original due to historical and geographical reasons. The various trajectories of shrinkage in Western and CEE cities indicated by Turok and Mykhenko (2007, 2008) suggest that

\footnotetext{
10 There were 6966 vacant dwellings out of a total of 354,000 in 2016. Likewise, in Katowice, only $1.3 \%$ of the dwellings were empty in 2016 (CSO).
} 
the origins and course of shrinkage processes may be distinct; therefore, demographic transitions alone are not sufficient for understanding and explaining the burden of urban shrinkage, among which are socio-economic processes linked to globalization, deindustrialization, and metropolization. This is very often why cities undergoing shrinkage are medium-sized cities with a monofunctional profile. The case of Łódź is somehow different. Indeed, it was - and still is - an industrial city. However, unlike the majority of declining cities in the world, it is also a major city in the Polish national urban network with many administrative functions due to its role in the administrative structure of the country as the capital city of the Łódź Voivodeship. It was the second-largest city in terms of population until 2007, and it is now the third. It is possibly a very rare shrinking metropolis. This is an exception that must be explained. The city was born as a textile city, it was not expected to become such a big city, and it suffered from a delay in developing administrative, cultural, and scientific functions adapted to its size and its history of development (Liszewski 2009). Furthermore, it is situated almost in the shadow of the capital city of Warsaw (140 km away, less than $2 \mathrm{~h}$ by train and by car), which encourages the outmigration of students or workers in high-skilled jobs. This outmigration also happens very often abroad; in this respect, Łódź is very similar to other Polish cities, but not to average European cities. Thus, the potential gentrification process downtown is held back because some social or cultural elites have left the city. At the least, the case study of Łódź qualifies the relationship between the economic situation and urban shrinkage. In recent years, public and private authorities at the local and national scales have driven a better situation in the labour market and investments. The unemployment rate, which was dramatically high (approximately $20 \%$ ) in the 1990s, reached only $4 \%$ in 2016, and the city had been attracting many foreign direct investments for the 1990s. Meanwhile, demographic decline has been occurring because of ageing and migration (which explains the low unemployment rate).

Acknowledgements The authors thank the anonymous reviewers for their suggestions that helped improve this paper.

Funding This work was supported by National Science Centre of Poland [Grant Number: DEC-2014/15/B/ HS4/01940].

\section{Compliance with ethical standards}

Conflict of interest No potential conflict of interest was reported by the authors.

Open Access This article is distributed under the terms of the Creative Commons Attribution 4.0 International License (http://creativecommons.org/licenses/by/4.0/), which permits unrestricted use, distribution, and reproduction in any medium, provided you give appropriate credit to the original author(s) and the source, provide a link to the Creative Commons license, and indicate if changes were made.

\section{References}

Audirac, I., Cunningham-Sabot, E., \& Fol, S. (2012). Declining suburbs in Europe and Latin America. International Journal of Urban and Regional Research, 36, 226-244.

Bański, J., \& Ferenc, M. (2013). "International” or "Anglo-American” journals of geography? Geoforum, 45, 285-293.

Bayou, C., \& Le Bouhris, É. (2017). Les Lettons. Paris: Atelier Henry Dougier. 
Béal, V., Fol, S., Miot, Y., \& Rousseau, M. (2017). Varieties of right-sizing strategies: Comparing degrowth coalitions in French shrinking cities. Urban Geography. https://doi.org/10.1080/02723638.2017.13329 27.

Beauregard, R. A. (2009). Urban population loss in historical perspective: United States, 1820-2000. Environment and Planning A, 41, 514-528.

Bernt, M. (2009). Partnerships for demolition: The governance of urban renewal in east German shrinking cities. International Journal of Urban and Regional Research, 33, 754-769.

Botterill, D., \& Platenkamp, V. (2012). Key concepts in tourism research. Los Angeles: Sage.

Brainerd, E. (2012). The demographic transformation of post-socialist countries: Causes, consequences, and questions. In G. Roland (Ed.), Economies in transition. Studies in development economics and policy (pp. 57-83). London: Palgrave Macmillan.

Cirtautas, M. (2013). Urban sprawl of major cities in the Baltic states. Architecture and Planning, 7, $72-79$.

Coudroy de Lille, L. (2013). Le logement en République populaire de Pologne: du "déficit" à la "crise". Le Mouvement Social, 4(245), 109-122.

Coudroy de Lille, L., \& Wolaniuk, A. (2005). Łódź, ou les ressources territoriales d'une stratégie métropolitaine. Géocarrefour, 80, 35-48.

Cunningham-Sabot, E., \& Fol, S. (2009). Shrinking cities in France and Great Britain: A silent process? In K. Pallagst, J. Aber, I. Audirac, E. Cunningham-Sabot, S. Fol, C. Martinez-Fernandez, S. Moraes, H. Mulligan, J. Vargas-Hernandez, T. Wiechmann, T. Wu, \& J. Rich (Eds.), The future of shrinking cities-Problems, patterns and strategies of urban transformation in a global context (pp. 17-27). California: Center for Global Metropolitan Studies, Institute of Urban and Regional Development, and the Shrinking Cities International Research Networks.

Dzieciuchowicz, J., \& Groeger, L. (2016). Nowa przestrzeń mieszkaniowa: Lofty i rezydencje w Łodzi. Łódź: Łódź University Press.

Geshkov, M. (2015). Urban sprawl in eastern Europe: The Sofia City example. Economic Alternatives, 2, 101-116.

Groeger, L. (2002). Struktura przestrzenna obszarów najwyżej preferowanych na miejsce zamieszkania w Łodzi. In I. Jażdżewska (Ed.), Wspótczesne formy osadnictwa miejskiego i ich przemiany (pp. 91-98). Łódź: ŁTN.

Guba, E., \& Lincoln, Y. S. (1989). Fourth generation evaluation. Newbury Park, CA: Sage.

Haase, D. (2006). Beyond growth? Decline of the urban fabric in Eastern Germany: A spatially explicit model approach to predict residential vacancy and demolition priorities. In E. Koomen, A. Bakema, J. Stillwell, \& H. Scholten (Eds.), Modelling land-use change (pp. 339-353). Dordrecht: Springer.

Haase, A., Bernt, M., Grossmann, K., Mykhnenko, V., \& Rink, D. (2013). Varieties of shrinkage in European cities. European Urban and Regional Studies, 12, 1-17.

Haase, A., Rink, D., Grossmann, K., Bernt, M., \& Mykhnenko, V. (2014). The concept of urban shrinkage. Environment Planning A, 46(7), 1519-1534.

Haase, A., Bernt, M., Grossmann, K., Mykhnenko, V., \& Rink, D. (2016a). Varieties of shrinkage in European cities. European Urban and Regional Studies, 23(1), 86-102.

Haase, A., Rink, D., \& Grossman, K. (2016b). Shrinking cities in post-socialist Europe: What can we learn from their analysis for theory building today? Geografiska Annaler: Series B, Human Geography, 98(4), 305-319.

Hager, F., \& Schenkel, W. (2003). Schrumpfungen. München: Oekom.

Holm, A., Marcińczak, S., \& Ogrodowczyk, A. (2015). New-build gentrification in the post-socialist city: Łódź and Leipzig two decades after socialism. Geografie - Sborník ČGSR, 120(2), 164-187.

Hondrich, K. O. (2007). Weniger sind mehr: Warum der Geburtenrückgang ein Glücksfall für unsere Gesellschaft ist. Frankfurt: Campus Verlag.

Jakóbczyk-Gryszkiewicz, J. (1997). Demographic characteristic of Łódź. In S. Liszewski \& C. Young (Eds.), A comparative study of Łódź and Manchester (pp. 111-124). Łódź: Łódź University Press.

Kabisch, S., Steinfurer, A., Haase, A., Grossmann, K., Peter, A., \& Maas, A. (2008). Demographic change and housing in European cities. Leipzig: Helmholtz Centre for Environmental ResearchUFZ, Department of Urban and Environmental Sociology.

Kabisch, N., Haase, D., \& Haase, A. (2012). Urban population development in Europe 1991-2008. The examples of Poland and the UK. International Journal of Urban and Regional Research, 36, 1326-1348.

Kaczmarek, S., Kazimierczak, J., Coudroy de Lille, L., \& Mongeard, L. (2018). Demolowanie terenów miejskich: synergia w badaniach geograficznych w Polsce i we Francji. In M. Więckowski, M. Jędrusik, L. Coudroy de Lille, \& A. Le Blanc (Eds.), Geografia. Wspólne idee, wspólne wizje. Sto lat wspótpracy polsko-francuskiej (pp. 97-114). Warsaw: Wydział Geografii i Studiów Regionalnych UW. 
Kazimierczak, J. (2014a). Wpływ rewitalizacji terenów poprzemystowych na organizację przestrzeni centralnej w Manchesterze, Lyonie i Łodzi. Łódź: Łódź University Press.

Kazimierczak, J. (2014b). Kształtowanie przestrzeni publicznej miasta w kontekście rewitalizacji terenów poprzemysłowych w Manchesterze, Lyonie i Łodzi. Studia Miejskie, 16, 115-128.

Kazimierczak, J. (2014c). Revitalization and its impact on public space organization: A case study of Manchester in UK, Lyon in France and Łódź in Poland. TeMa Journal of Land Use Mobility and Environment-Smart Cities: Planning for Energy, Transportation and Sustainability of the Urban System, Special Issue, 545-556.

Kazimierczak, J., \& Kosmowski, P. (2017). In the shadow of urban regeneration megaproject: Urban transitions of downtown in Łódź. Poland. Urban Development Issues, 56(4), 39-50.

Kennedy, M. M. (1976). Generalizing from single case studies. Evaluation Quarterly, 3, 661-678.

Kil, W. (2004). Luxus der Leere. Vom schwierigen Rückzug aus der Wachstumswelt. Wuppertal: Müller und Busmann.

Kovács, Z. (1999). Cities from state-socialism to global capitalism: An introduction. GeoJournal, 40, 1-6.

Krzysztofik, R., Dymitrov, M., Szmytkie, R., Kantor-Pietraga, I., Pełka-Gościniak, J., \& Spórna, T. (2015). Environmental hazards and urban abandonment: Case studies and typological issues. Geografiska Annaler: Series B, Human Geography, 97(4), 291-308.

Kubiczek, F. (1994). Terytorium [History of Poland in numbers. Population. Territory]. Warszawa: Główny Urząd Statystyczny.

Lesthaeghe, R., \& van de Kaa, D. J. (1986). Twee demografische transities? (pp. 9-24). Bevolking: Groei en Kremp.

Liszewski, S. (2009). Łódź: A monograph of the city. Łódź: Łódź Scientific Society.

Martinez-Fernandez, C., Weyman, T., Fol, S., Audirac, I., Cunningham-Sabot, E., Wiechmann, T., et al. (2016). Shrinking cities in Australia, Japan, Europe and the USA: From a global process to local policy responses. Progress in Planning, 105, 1-48.

Mladenov, Ch., Dimitrov, E., \& Kazakov, B. (2008). Demographical development of Bulgaria during the transitional period. Méditerranée, 110, 117-124.

Mykhnenko, V., \& Turok, I. (2008). East European cities-Patterns of growth and decline, 1960-2005. International Planning Studies, 13, 311-342.

Neill, W. J. V., \& Schlappa, H. (Eds.). (2016). Future directions for the European shrinking city. New York: Routledge.

Oswalt, P., \& Rieniets, T. (2006). Atlas of shrinking cities. Ostfildern: Hatje Canz.

Radzimski, A. (2016). Changing policy responses to shrinkage: The case of dealing with housing vacancies in Eastern Germany. Cities, 50, 197-205.

Reckien, D., \& Martinez-Fernandez, C. (2011). Why do cities shrink? European Planning Studies, 9, 1375-1397.

Robinson, J. (2006). Ordinary cities: Between modernity and development. London: Routledge.

Roth, H. (2011). Les villes rétrécissantes en Allemagne. Géocarrefour, 88(2), 75-80.

Salamon, M., \& Muzioł-Węcławowicz, A. (2015). Mieszkalnictwo w Polsce. Analiza niektórych obszarów polityki mieszkaniowj. Warsaw: Habitat for Humanity.

Schatz, L. (2010). What helps or hinders the adoption of "good planning" principles in shrinking cities? A comparison of recent planning exercises in Sudbury, Ontario and Youngstown, Ohio. Waterloo: University of Waterloo.

Sjöberg, Ö. (2014). Cases onto themselves? Theory and research on ex-socialist urban environments. Geografie, 119(4), 299-319.

Špačková, P., Dvořácková, N., \& Tobrmanová, M. (2016). Residential satisfaction and intention to move: the case of Prague's new suburbanities. Geografiska Annaler: Series B, Human Geography, 98(4), 331-348.

Stake, R. E. (1998). Case studies. In N. K. Denzin \& Y. S. Lincoln (Eds.), Strategies of qualitative inquiry (pp. 86-109). Thousand Oaks, CA: Sage.

Stanilov, K. (2007). The post-socialist city: Urban form and space transformations in central and eastern Europe after socialism. Dordrecht: Springer.

Struyk, R. (2000). Introduction. In R. Struyk (Ed.), Homeownership and housing finance policy in the former Soviet Bloc: Costly populism (pp. vii-xiii). Washington, DC: The Urban Institute.

Stryjakiewicz, T., Ciesiółka, P., \& Jaroszewska, E. (2012). Urban shrinkage and the post-socialist transformation: The case of Poland. Built Environment, 38, 197-213.

Stryjakiewicz, T. (2013). The process of urban shrinkage and its consequences. Romanian Journal of Regional Science, Special Issue on New Urban World, 7, 29-40. 
Stryjakiewicz, T., \& Jaroszewska, E. (2014). Kurczenie się miast w Polsce. In T. Stryjakiewicz (Ed.), Kurczenie się miast w Europie Środkowo-Wschodniej (pp. 67-77). Poznań: Bogucki Wydawnictwo Naukowe.

Szafrańska, E. (2008). Kapitał ludzki i społeczny w przestrzeni miasta. Przykład Łodzi. In J. Słodczyk \& E. Szafranek (Eds.), Mechanizmy i uwarunkowania budowania konkurencyjności miast. Opole: Opole University Press.

Szafrańska, E. (2013). Large housing estates in post-socialist Poland as a housing policy challenge. European Spatial Research and Policy, 20, 119-129.

Szafrańska, E. (2014). Transformations of large housing estates in post-socialist city: The case of Łódź, Poland. Geographia Polonica, 87, 77-94.

Szafrańska, E. (2016). Residential attractiveness of the inner city of Lodz in the opinions of city inhabitants. Studia Regionalia, 45, 8-21.

Szafrańska, E., \& Mularska-Kucharek, M. (2016). Selected aspects of the quality of life of the inhabitants of large housing estates in Lodz. Socio-Spatial Context, Studia Regionalia, 45, 60-78.

Szukalski, P. (2012). Sytuacja demograficzna Łodzi. Łódź: Wydawnictwo Biblioteka.

Tellis, W. M. (1997). Introduction to case study. The Qualitative Report, 3, 1-14.

Temelová, J., Novák, J., Kährik, A., \& Tammaru, T. (2016). Neighborhood trajectories in the inner cities of Prague and Tallin: What affects the speed of social and demographic change? Geografiska Annaler: Series B, Human Geography, 98(4), 349-366.

Tsenkova, S. (2000). Housing in transition and the transition in housing: Experiences of Central and Eastern Europe. Sofia: Kapital Reclama.

Turok, I., \& Mykhnenko, V. (2007). The trajectories of European cities, 1960-2005. Cities, 24(3), 165-182.

Turok, I., \& Mykhnenko, V. (2008). East European cities-Patterns of growth and decline, 1960-2005. International Planning Studies, 13, 311-342.

Warzywoda-Kruszyńska, W., Grotowska-Leder, J., \& Krzyszkowski, J. (Eds.). (2003). Lokalna polityka wobec biedy i pomocy społecznej. Łódź: WUŁ.

Węcławowicz, G. (2007). Geografia społeczna miast. Warszawa: Wydawnictwo Naukowe PWN.

Wiechmann, T. (2009). Conversion strategies under uncertainty in post-socialist shrinking cities-The example of Dresden in Eastern Germany. In K. Pallagst, J. Aber, I. Audirac, E. Cunningham-Sabot, S. Fol, C. Martinez-Fernandez, S. Moraes, H. Mulligan, J. Vargas-Hernandez, T. Wiechmann, T. Wu, \& J. Rich (Eds.), The future of shrinking cities-Problems, patterns and strategies of urban transformation in a global context (pp. 5-16). California: Center for Global Metropolitan Studies, Institute of Urban and Regional Development, and the Shrinking Cities International Research Networks, University of California.

Wiechmann, T., \& Bontje, M. (2015). Responding to tough times: Policy and planning strategies in shrinking cities. European Planning Studies, 23, 1-11.

Wiechmann, T., \& Pallagst, K. M. (2012). Urban shrinkage in Germany and the USA: A comparison of transformation patterns and local strategies. International Journal of Urban and Regional Research, $36,261-280$.

Wojnarowska, A. (2011). Rewitalizacja zdegradowanych obszarów miejskich. Zagadnienia teoretyczne. Łódź: Łódź University Press.

Wójcik, M., \& Tobiasz-Lis, P. (2014). Ocena przestrzennych dysproporcji w Łodzi z perspektywy mieszkańców miasta. In A. Suliborski \& M. Wójcik (Eds.), Dysproporcje społeczne i gospodarcze $w$ przestrzeni Łodzi. Czynniki, mechanizmy, skutki (pp. 305-320). Łódź: Łódź University Press.

Van de Kaa, D. J. (2003). The idea of a second demographic transition in industrialized countries. Japanese Journal of Population, 1, 42-75.

Yin, R. K. (2014). Case study research: Design and methods. London: Sage.

Ziobrowski, Z., \& Domański, B. (2010). Rewitalizacja miast polskich jako sposób zachowania dziedzictwa materialnego i duchowego oraz czynnik zrównoważonego rozwoju. Podsumowanie projektu. Kraków: Instytut Rozwoju Miast w Krakowie.

\section{Other sources}

Act on Regeneration. Journal of Laws [Dz. U.] of 2015, item 1777, of 2016, items 1020, 1250

Central Statistical Office in Poland

City of Łódź CSO

Gminny Program Rewitalizacji: Program Rewitalizacji Łodzi 2026+ (2016)

Polityka mieszkaniowa Łodzi 2020+ (2012)

Łódź City Council 
Łódź in figures (2008)

National Census in 1978, 1988, 1995, 2002, 2011

Statistical Office in Łódź

\section{Affiliations}

\section{Ewa Szafrańska ${ }^{1}$ (D) Lydia Coudroy de Lille $^{2} \cdot$ Jarosław Kazimierczak $^{3}$}

Lydia Coudroy de Lille

lydia.coudroydelille@univ-lyon2.fr

Jarosław Kazimierczak

jaroslaw.kazimierczak@geo.uni.lodz.pl

1 Department of Urban Geography, Institute of Urban Geography and Tourism Studies, Faculty of Geographical Sciences, University of Lodz, 31 Kopcińskiego St., 90-142 Lodz, Poland

2 Université de Lyon (Lumière Lyon 2) UFR Temps \& Territoires, 5 avenue Pierre Mendès France, 69676 Bron cedex, France

3 Urban Regeneration Laboratory, Institute of Urban Geography and Tourism Studies, Faculty of Geographical Sciences, University of Lodz, 31 Kopcińskiego St., 90-142 Lodz, Poland 